\title{
Aspectos formales en la marginalia del Maimónides de Copenhague *
}

\author{
Rosa Alcoy i Pedrós **
}

Las ilustraciones del códice hebreo ( $\mathrm{n}$. XXXVII de la Kongelige Bibliotek) conocido entre los historiadores del arte como «Maimónides de Copenhague" han sido analizadas normalmente desde el punto de vista de las representaciones principales que aparecen en los folios $3 \mathrm{v}, 34 \mathrm{r}, 114 \mathrm{r}$ y $202 r^{\dagger}$ (figs. 1 y 2). Sin embargo, este ejemplar de la Guía de Perplejos (Ductor Perplexorum) de Moisés Maimónides, copiado en Barcelona el año $5108(1347-48)^{2}$, contiene también una rica e interesante decoración marginal que debe ser objeto de estudio. Hecho aparte de las discusiones acerca de la autoría global del manuscrito, sobre la que se han vertido diversos pareceres, que no puedo dejar de tener en cuenta, pretendo examinar aquí, aunque sea con cierta brevedad, el valor y características más sugerentes de aquellas figuraciones que, equívocamente, definiríamos como secundarias y que aparecen en los márgenes del libro, acompañando al lector y trascendiendo quizás el significado de las escenas y representaciones más notables. El principal propósito de mi intervención sería, en definitiva, dar merecido relieve a la aportación gráfica que aún cabe descubrir en este bello libro, copiado por Leví Ben Ishaq, Fijo Caro, a través de las marginalia del códice, para poder establecer, más adelante

* Comunicación presentada en el Encuentro Internacional de Historiadores En torno a Sefarad. Toledo, 1991.

$\star \star$ Universidad de Barcelona.

1 Deseo agradecer al Dr. Uif Haxen, conservador de la sección Hebraica y Judaica de la Kongelige Bibliotek de Copenhague, las muestras de interés y las facilidades que, en todo momento, dio a este trabajo, proporcionando materiales fotográficos y bibliográficos que han sido básicos para la fundamentación del mismo.

2 Sobre la datación de la copia del manuscrito en el año 5108 del cómputo judío nos remitiremos a las precisiones del profesor Romano, David, en «En torno a Menahem, físico y alquimista judío de los reyes de Mallorca y Aragón (1344-1348)", XIII Congrés d'Història de la Corona d'Aragó, Comunicacions II. (Palma de Mallorca, set-oct, 1987), Institut d'Estudis Baleàrics, Palma de Mallorca, 1990, págs. 95-102. David Romano sitúa la realización de la copia entre el 6-9-1347 y el 24-8-1348 y nos ofrece también una "hipótesis biográfica" que permite iniciar la reconstrucción de la figura del comitente de esta obra, R. Menahem Besalel, médico, físico y alquimista. Véase asimismo Bezalel Narkiss, Hebrew Illuminated Manuscripts, New York, 1969, n. ${ }^{\circ} 18$, pág. 76 y 170. 
y dentro de lo posible, una comparación con otros manuscritos contemporáneos, tanto judíos como cristianos, que también conceden a este tipo de ilustración «secundaria» un lugar principal.

Se trata de un códice de pequeño formato $(19,5 \times 13 \mathrm{cms})$ que desarrolla la relación de texto e imágenes a lo largo de 318 folios de un total de $352^{3}$. Su realización se ha situado desde antiguo en el contexto de la ilustración catalana del siglo xIV ${ }^{4}$. Sin embargo, la autoría efectiva de las miniaturas parece todavía hoy tema de debate. Se ha hablado del pintor e ilustrador Ramón Destorrents (1351-1362...), de Arnau de la Pena, documentado sólo como miniaturista, e incluso del taller de los Bassa, en particular de Arnau Bassa (1345-1348) ${ }^{5}$. Sin embargo, desde el momento en que Ferrer Bassa, autor de los murales de la capilla de San Miguel del monasterio de Pedralbes, puede convertirse en el maestro que elabora 10 más importante del Salterio anglo-catalán de París y quizás también en la cabeza visible de un equipo de miniaturistas que decora el Libro de Horas de María de Navarra con anterioridad al 1347, es evidente que, la ilustración del Maimónides entra de lleno en la problemática de este complejo grupo de obras, resituadas desde hace ya algunos años

\footnotetext{
3 Parece ser que este ejemplar de la Guía de Perplejos sería comprado en Amsterdam durante el siglo XVII por el teólogo Hans Bartholin (1665-1731), quien lo ofreció a Frederik Rostgaard. El siguiente poseedor fue el conde Christian Danneskjold Samsoe, coleccionista de libros. A su muerte en el 1732, el Maimónides ingresaría en los fondos de la Biblioteca Real. Para estas y otras precisiones veánse algunos de los catálogos recientes en que aparece ficha del manuscrito: HAXEN, Ulf, Kings and Citizens, The History of the Jews in Denmark 1622-1983 II. Manuscripts and Printed Books from the Collection of the Royal Library. New York 1983. n. 6 págs. 18-19; Maimónides y su época (a cargo de David Romano). Córdoba 1986, pág. 47, n. 50 .

4 Además de las referencias que se ofrecen en los textos generales dedicados a la miniatura hispánica y catalana (Domínguez Bordona, José y AInAud, Joan, Miniatura, Grabado, Encuadernación (Ars Hispaniae, vol. XVIII). Madrid 1962, pág. 148, fig. 189; BoHIGAS, Pere, La ilustración del Libro manuscrito en Cataluña, 3 vols., Barcelona 1960-1967, vol. II, págs. 122-124, nota $110)$ se hallarán otras indicaciones en WORMALD. Francis, «Afterthoughts on the Sotckholm Exhibition", Sartryck ur Konsthistorisk Tidskrift, XXII, 1953, 3-4, págs. 75-84; también en WORMALD, Francis, Collected Writings. II. Studies in English and Continental Art of the Later Middle Ages. Londres/New York 1988, págs. 147-152, figs. 131-132; GuDIOL i RICART, Josep. Pintura Gótica (Ars Hispaniae, vol. IX). Madrid 1955; BohIGAS, Pere, "L'agrupament de les miniatures del Llibre Vermell", dins Miscel.lania Anselm M. Albareda, I, Analecta Montserratensia, VII, 1958, pág. 3952, 43-44; NaRkiss, Bezalel, Hebrew ulluminated manuscripts. New York 1969, págs. $76-77$ y 170; SED-RAJNA, Gabrielle, "Ateliers de manuscrits hébreux dans l'Occident médiéval", Artistes, artisans et production artistique au Moyen Age, vol. I. (Rennes 1983). París 1986, págs. 339-351, fig. 7; ALcoY, Rosa, "El Maimónides de Copenhagen", en La Introducció $i$ derivacions de l'italianisme a la pintura gòtica catalana: 1325-1350, 3 vols. Barcelona 1988 (tesis doctoral, existe publicación en microficha, Universidad de Barcelona, 1989), vol. II, págs. 537-544.

5 Hay que tener en cuenta el estado de la cuestión posterior a la aportación de Meiss. Millard, "Italian Style in Catalonia and a Fourteenth Century Catalan Workshop", The Journal of the Walters Ast Gallery, IV, 1941, págs. 45-87.
} 
en el espacio temporal de la primera mitad del siglo xIV. Entre las mismas, aunque con matices, hay que citar también el libro de Usatges conocido como Llibre Verd (Archivo Histórico Municipal de Barcelona) y los volúmenes del Decretum Gratiani conservado en la British Library de Londres.

La datación del Maimónides, abocada al 1348, coincide con el momento de la desaparición de los Bassa. Este hecho obliga a contemplar el manuscrito como una de las últimas producciones del taller barcelonés. Por tanto, deberemos pensar en los últimos años de la actividad de Ferrer Bassa y en un momento en que el estilo de Arnau se encuentra perfectamente definido y diferenciado del que atribuimos a su padre. En este sentido, es posible concretar algo más la autoría de las miniaturas de este códice. En ningún momento se advierte un trabajo cercano al del Maestro de San Marcos, identificado con Arnau Bassa. Contrariamente, existen elementos suficientes para aproximar al menos las ilustraciones centrales a algunas de las realizaciones de Ferrer. Ciertas similitudes entre éstas y los murales de Pedralbes, finalizados en 1346, se detectan fácilmente, no obstante haya que comprender previamente el cambio de escala y de "técnica" entre los términos de la comparación.

Una alternativa completamente distinta a los Bassa es aquella que propuso Rhaphael Edelmann en 1954 y que se recoje en el Catálogo de 1983. Kings and Citizens. Este autor contempla la posibilidad de atribuir al copista Levi bar Isaac. "Hijo Caro" de Salamanca, la ilustración del Maimónides. El nombre del copista aparece en el colofón del libro (folio 316), acompañado de la fecha, cercana al 1348, y de la mención del comitente del trabajo, el físico barcelonés Menahem Bezalel ${ }^{6}$.

La dificultad que imponía este año cara a la atribución de las miniaturas hizo pensar en algún momento que podía tratarse de una fecha copiada de una versión anterior del mismo texto. Siendo una copia mimética de un libro anterior, podían superarse los inconvenientes cronológicos que suponía una datación tan temprana frente al grupo de piezas atribuidas por aquel entonces al "Maestro de San Marcos", todavía considerado como un anónimo activo dentro de la segunda mitad del siglo xIv. Con todo, esta explicación se antojaba como probabilidad remota. La cronología del grupo de San Marcos no se hallaba esclarecida por completo $y$, en consecuencia, también era factible que el conjunto de códices a que se aludía fuesen encabezados por la Guía de Perplejos de Copenhague ${ }^{7}$. Por tanto, se pensó, erróneamente, que quizás se tratara de la

- Sobre la atribución de las ilustraciones a Isaac Levi véase Kings and Citizens..., pág. 156. Una transcripción del colofón aparece en WORMALD, F. "Afterthoughts...", pág. 172, nota 3.

Vid., Wormald, F., "Afterthoughts...," y BohiGas, P., "L'agrupació...", pág. 44. 
primera realización conocida de este taller, o talleres, relacionados por un estilo común. En la actualidad este debate debe seguir un curso diferente. Las contradicciones derivadas de esta visión, ya antigua, parecen resolverse desde el descubrimiento del Libro de Horas de la reina María de Navarra de la Biblioteca Marciana de Venecia, necesariamente anterior al 1347. Desde ese momento, como se ha advertido, al menos una parte de las obras que configuraban el grupo de San Marcos pasan a engrosar el catálogo del taller de los Bassa.

Dentro de este contexto, pensar en Levi bar Isaac como ilustrador del Maimónides catalán obligaría a supeditar su actuación, en términos generales, al registro estilístico que el taller de los Bassa y, más concretamente, a la tendencia que dentro de este define el maestro del Salterio de Paris (Ferrer), y que quedará bien perfilada entre el 1333 y el 1348 , ya que, en contrapartida, es completamente inverosímil la sola idea de atribuir a este escribano la realización de las pinturas del círculo del Maestro de San Marcos, invirtiendo los términos de comparación ${ }^{8}$. Por consiguiente, plantearemos como hipótesis de partida la atribución de las miniaturas que decoran la Guía de perplejos al taller de los Bassa, teniendo en cuenta sobre todo su relación con los códices hasta ahora mencionados y con el estilo que también definen algunas conocidas pinturas murales y sobre tabla. Llegados a este punto, pueden plantearse algunos de los interrogantes que surgen del análisis de los marginalia.

\section{ORDEN Y DESORDEN EN LA MARGINALIA: PUERTAS A OTROS MARGINALIA EN LAS ESCENAS PRINCIPALES}

El Maimónides contiene una única miniatura a página entera en el folio $3 v$ (fig. 1). Desafortunadamente esta pintura fue borrada, de forma que la lectura de la imagen se ha dificultado de manera considerable. Quizás se trató de un accidente o de una actuación intencionada, no lo sabemos $y$, en cualquier caso, desconocemos la causa. En ella aparecen dos composiciones superpuestas que llenan el espacio rectangular de la pági$\mathrm{na}^{9}$; en su rededor y adoptando una disposición radial se disponen al-

8 Sobre la actividad de miniaturistas judíos vid. HILLGarth. J. N. y Narkiss, B., "A list of Hebrew Books (1330) and a contract to illuminate manuscripts (1335) from Majorca”, Revue des Études Juives, XIX, 1961, págs. 297-320, donde también se menciona el Maimónides, considerándolo bajo influjo italiano, en particular boloñés y, explícitamente, no sienés. A nuestro parecer, si admitimos la dependencia de este libro de la órbita de Ferrer Bassa, la influencia italiana que se detecta en él nos aproximará a algunas frecuencias toscanas, que incluyen las florentinas, pero también a algunas de las realizaciones umbras y napolitanas, zonas donde lo florentino y los sienés pueden llegar a confluir muy positivamente.

${ }^{2}$ En el primer episodio se advierte la presencia de dos figuras con libros en las manos. El 


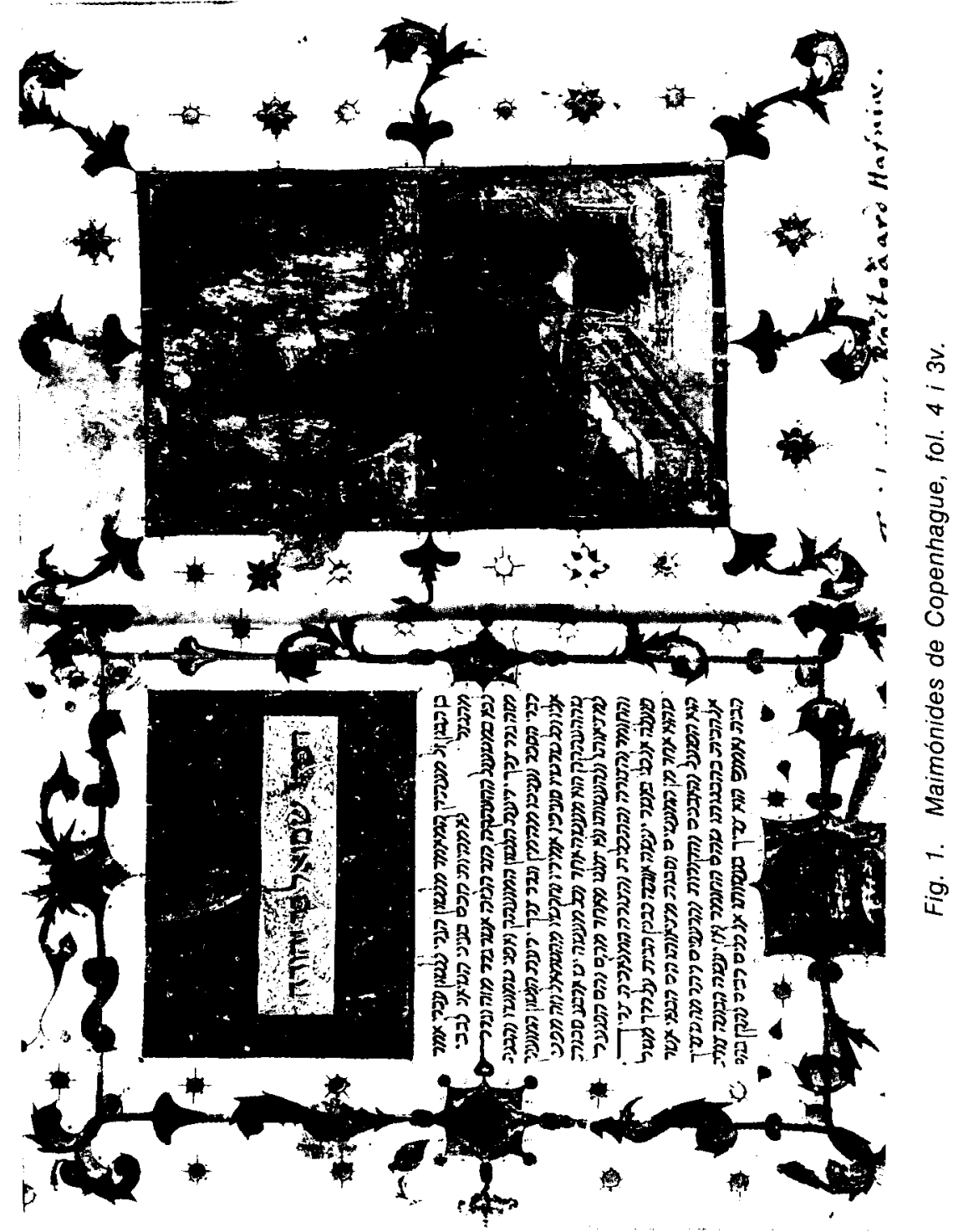




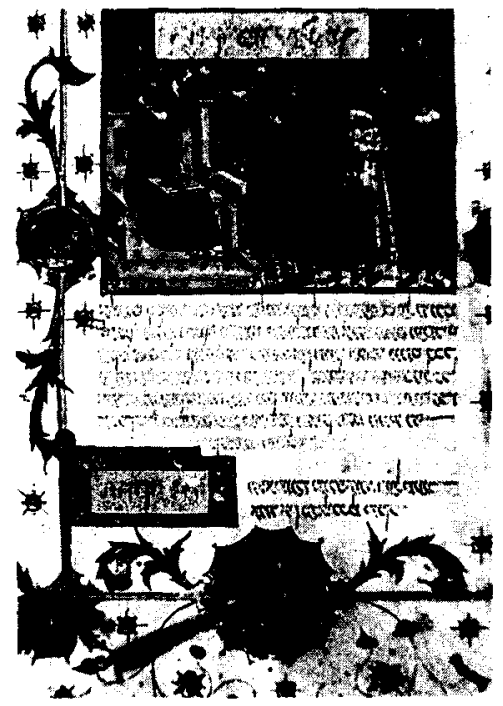

Fig. 2. Marginalia del Maimónides de Copenhague, fol. 114 (detalle).

gunos motivos vegetales; también se incluyen botones dorados de diversa complejidad y caracterización floral, que recrean la estructura rectangular de la miniatura. En el Libro de Horas de María de Navarra pueden estudiarse diversas variantes de esta misma solución que permite subrayar el marco de cada miniatura. Sin embargo, es en los folios siguientes donde va a organizarse una marginalia más compleja y sugestiva.

En el folio 4 un escudo corona una inscripción en hebreo, enmarcada por un campo decorado siguiendo los esquemas que llenan también el fondo de las superficies historiadas (fig. 1). Una orla vegetal que envuelve todo el folio sirve de escondrijo a algunas aves. La más vistosa es un pavo real que superpone la cola al marco que inscribe su figura en la parte inferior del folio. También apreciamos la presencia de un conejo, o roedor de largas orejas, de una lechuza, de una perdiz y, quizás, de un jilgero.

personaje de la izquierda se halla claramente sentado. En la viñeta inferior, algo más nitida, un hombre con una vara en la mano y un libro sobre la rodilla se dirije, desde un sitial preeminente, a un grupo de cuatro sujetos que, en la parte izquierda del cuadro, se encuentran sentados en una mesa alargada, que unifica su lugar de emplazamiento, en actitud de estudio o lectura. En el fondo de la escena aparecen las típicas tramas ajedrezadas, en este caso con juegos romboidales, que también se utilizaron en el Salterio y en las Horas de María de Navarra. 
El folio 114 contiene el segundo de los cuadros historiados, sin duda el más divulgado del libro (fig. 2). Según parecer de Joseph Gutmann, esta pintura representa a Aristóteles explicando la creación del mundo ${ }^{10}$. Otros autores se amparan en una identificación menos concreta, considerando más acertada la visión de un astrónomo con un astrolabio en la mano - recuérdese que el libro era destinado a un físico, Menahem Bezalel- que explica a sus discípulos las leyes de la naturaleza y los atributos de la divinidad. Desde una óptica más sencilla podría pensarse en un sabio que muestra diversos resultados de experiencias, verificables gracias al aparato que tiene entre manos, a otros personajes que parecen observar con curiosidad al tiempo que comentan sus observaciones. En cualquier caso, la figura a que nos referimos, un hombre barbado, vestido de azul y situado sobre un trono poblado de estrellas de David, parece coincidir con la del sabio o maestro que también aparecía en el folio 3. A él, destacado sobre los asistentes, se acercan tres personajes; el primero de ellos vestido de azul claro, señala el astrolabio a un segundo de cabellera anaranjada y túnica roja que mira con curiosidad, por encima del hombro de su compañero, el que aparece como maravilloso instrumento de precisión. El tercero de ellos, con túnica verde, distrae su atención ante el comentario de dos sujetos más que hablan en el margen izquierdo a la vez que observan el cielo poblado de estrellas, donde también vemos la representación del sol y de la luna. Este firmamento, absolutamente convencional, se recorta en la parte superior de la escena utilizando el mismo azul matizado que viste a dos de los personajes, destacado sobre un fondo de color naranja. Interpuesta entre el cielo y los dos grupos de personajes aparece una nueva inscripción en hebreo. La escena del diálogo y comunicación entre diversos grupos de personajes alrededor del que muestra el astrolabio puede encontrar algún patrón semejante en el Salterio de París, donde las reuniones entre algunas personas que hablan o discuten sobre una cuestión gozan de diversos grados de complejidad y menudean a lo largo del manuscrito (folios 111 , $121 v, 124,126 \ldots)$. Por desgracia para nuestras comparaciones, el Salterio no posee una marginalia comparable a la de otros códices del grupo que poder aproximar, como lo hacemos en el caso de los temas historiados, al Maimónides.

En este folio 114, una orla vegetal que incluye cuatro tondos, dos de fondo azul, a los lados, y dos de color naranja, en las zonas superior e inferior, sobre un enmarcamiento irregular de oro donde se inscriben fi-

10 Gutmann, Joseph, Buchmalerei in hebräischen Handchriften. Munich 1978, pág. 20, citado en Maimónides y su época..., pág. 147. 
guras de aves, se convierte en marco de esta miniatura y del fragmento de texto que la acompaña. Quizás podamos interpretar su papel como puerta de entrada o prólogo ornamental de la ilustración. El pavo real aparece de nuevo en el círculo que se sitúa al pie de la página, y arriba, en el mismo eje central, encontramos un faisán. En la izquierda se instala una perdiz y, al lado contrario, un gallo de colores vistosos, rojo y anaranjado, subrayados por el fondo azul. Estas imágenes y la orla vegetal que las enlaza en la configuración de un marco rectangular tienen paralelo en el folio 3 del Decretum Gratiani de Londres (Bristish Library, Add. 15274), al que deberemos referirnos también en relación con otras miniaturas del Maimónides. No son tampoco ajenas al grupo las hojas de acanto de caras reversibles que en esta página se muestran azules y rojas, como elementos dinámicos sobre los tallos de color anaranjado. Su coloración varía cuando el tronco vegetal, que ordena el estallido decorativo, adopta sus colores. La relación cromática puede invertirse entonces.

Al pie de la página cabe subrayar la característica decoración del tondo donde se sitúa el pavo real (fig. 2). Del fondo de oro enmarcado en negro nacen dos hojas de acanto dispuestas simétricamente hacia arriba, pero también dos finas líneas que se incurban como tallos menores hacia abajo, multiplicando las ramificaciones que permiten unir diversos motivos florales que incluyen botones de oro. Vale la pena fijar la atención en este recurso, que estiliza un motivo complementario que se utilizó, aunque menos afiligranado, en el Libro de Horas de María de Navarra.

En el folio 202 vuelve a repetirse el mismo tipo de encuadre que hemos visto en los folios 4 y 114 . Un ángel, una águila, un león y un toro alados, sobre contorno dorado flanquean los cuatro lados de una nueva inscripción. Así, las cuatro figuras que simbolizaron en otro contexto a los evangelistas, configurando el tetramorfos, comparecen aisladas sobre la superficie naranja, decorada con rombos de oro, con una significación que, lógicamente, no será la cristiana, pero que, sin embargo, se sirve abiertamente del modelo pictórico que, rodeando o no la imagen del Dios antropomorfo, aparece a menudo en códices catalanes de la época y también en aquellos que pertenecen al taller de Ferrer Bassa. Veámos por ejemplo el tetramorfos del folio 109v. del Salterio de París, donde las figuras del ángel, el águila, el león y el toro son portadoras de filacterias de identificación referidas a los cuatro evangelistas. Del mismo modo, el tema se repite en el folio $108 \mathrm{v}$. del códice de María de Navarra, cuando el tema representado es la Trinidad. Como es lógico, las filacterias rotuladas fueron pasadas por alto en el libro de Copenhague, desarrollando a pesar de todo el tema cristiano, bien conocido por el pintor con anterioridad. El águila de alas desplegadas tiene cabida también en el margen inferior del folio 227 del Libro de Horas, donde comparece aislada del 
tetramorfos y en una posición que guarda una cierta simetría y se diferencia, en este sentido, de la impostación más natural, o verosímil, elegida para esta ave rapaz en el códice de Copenhague ${ }^{11}$.

Debemos citar de nuevo el folio 3 del Decretum Gratiani de Londres, donde los símbolos de los cuatro evangelistas envuelven la miniatura principal, consagrada a la representación del Papa en su cátedra, acompañado de cardenales y obispos, del emperador y tres reyes, además de otros personajes. El tetramorfos se desplaza ahora a los ángulos del rectángulo, ubicándose cada símbolo sobre espacios muy semejantes a los ocupados por las aves en el folio 114 del Maimónides ${ }^{12}$.

La orla del folio 202 acoje también algunos pájaros en sus hojas, y muestra además, en los ángulos del rectángulo que dibuja, cuatro rostros tetralobulados superpuestos a marcos romboidales (fig. 4). Este aspecto singular vuelve a servir de enlace con el oracional de María de Navarra, lugar donde este tema alcanza un gran desarrollo. Sin embargo, el tipo concreto que se utiliza aquí no se encuentra entre las tipologías más comunes de rostros que estudiamos en el Libro de Horas (fig. $3,5-8)^{13}$. El modelo del Maimónides responde a una solución más abstracta que goza de algunas versiones semejantes en las Horas de la reina, pero que en este momento parece tender a simplificar los esquemas que tenían allí particular vigencia. De la misma forma que las orlas y cintas vegetales se adelgazan dando vida a un mundo más estilizado, que utiliza colores más

11 Otras soluciones puntuales unen la pintura del Maimónides a las fórmulas del Salterio de París. Comparemos el ángel del folio 203 del primero con algunas efigies infantiles del segundo (folio 166) o con los ángeles de la capilla de San Miguel en Pedralbes. También es posible observar la relación entre el trono que ocupa el astrónomo - folios 114 y $3 v$. de la Guía de Perplejos - y aquel en que aparece el rey David correspondiente al folio 126 del Salterio.

${ }_{12}$ WORMALD, "Afterthoughts...», fig. 133; MELNIKAS, Anthony, The Corpus of the miniatures in the manuscripts of Decretum Gratiani, Studia Gratiana, 3 vols. Roma 1957, vol. I, pl. XIX, pág. 5960. A Melnikas se mantiene todavía en el estadio que situaba la realización de las miniaturas catalanas del grupo de San Marcos en la segunda mitad del Trecento. Por otro lado, Melnikas comenta el simbolismo de la luna situada sobre el brazo secular, compuesto por el emperador y los reyes, y el sol que aparece sobre la figuras de los clérigos. Se tendrá en cuenta que sol y la luna son fuentes de luz desiguales. En este sentido es claro el simbolismo que nos habla de la segunda como dependiente del primero y que atañe también al secular conflicto entre los poderes terrenal y espiritual y a sus mutuas interdependencias. En otra circunstancia bien distinta, es factible recordar una semejante solución formal, en que la presencia de la luna y el sol, en el folio 114 del Ductor Perplexorum de Copenhague, se convierte en referencia a la observación del cielo estrellado.

13 Alcoy, Rosa, "Rostres profans i marginalia a Catalunya. Qüestions d'enfocament", D'Art n. 15, 1089, págs. 77-93 i ld., "Els rostres profans del Mestre de Baltimore i la seva incidència en les arts catalanes. Qüestions puntuals», Lambard, vol. IV (1885-1988), 1990, págs. 139-158 y 221-228. 


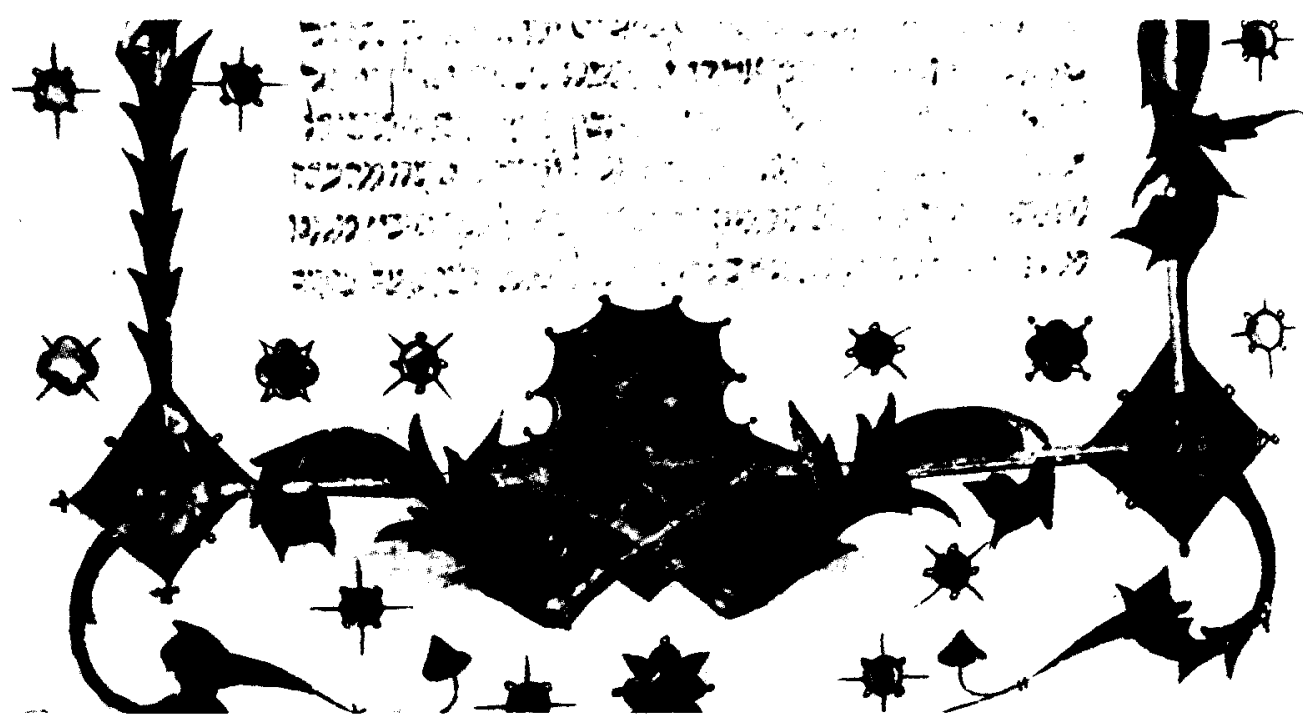

Fig. 4. Marginalia del Maimónides de Copenhague, fol. 202.

fuertes y densos, también los rostros parecen simplificación de un esquema utilizado con mayor profusión en los códices reales.

Descubrimos, por tanto, una regularidad bastante acusada en la ordenación de la marginalia que envuelve los cuadros principales. Todo queda organizado en base a los entrelazos de la vegetación que sobre troncos de diversos colores reconvierten las hojas de acanto en volutas, lazos o nudos que dan paso a algún ensanchamiento estratégicamente situado en los lugares donde cabe acentuar el margen, con una temática que se reduce casi exclusivamente a la definida por las aves domésticas y los rostros tetralobulados. Los botones dorados — por regla general más sencillos que en el Decretum Gratiani- complementan la decoración del espacio en blanco de la página manuscrita. También en el denominado Llibre Verd, códice de los Usatges, donde se nos muestran además las hojas grasas, habituales en la miniatura catalana (fig. 3); hojas que pueden ser de líneas dulces y tiernas, cromáticamente festivas, y que sin perder su intensidad cromática agudizan aquí sus recorridos. Su itinerario caligráfico se hace más nervioso y, a la vez, las soluciones finales son más tensas, sin llegar a la rigidez, sus resultantes son más duras y espinosas ya que estilizan los extremos de las hojas e introducen puntas muy afiladas. Aquí los marcos de los escudos sufren el mismo tipo de transformación. Las fórmulas redondeadas que pueden verse en las Horas de María de Navarra, integrando las insignias de la reina o, simplemente, decorando el pie de página, intercambian los lobulados y fórmulas curvas, 
los meandros y el arabesco de las hojas, por un enmarcamiento endurecido por aristas vivas que dibuja, recortando su silueta poligonal de caras cóncavas, una zona más relevante donde deberán emplazarse escudos u otros motivos. El Maimónides del 1348 retoma soluciones anteriores pero con una nueva visión a base de líneas muy finas que servirán de trazado a las hojas y que nos acercan a las alternativas del Llibre Verd barcelonés. También una parte del bestiario reaparece en este último. Por ejemplo el gallo del folio 114 del Maimónides que domina una orla en el folio 37 de los Usatges.

\section{NOTAS DE ANTROPOMORFISMO MARGINAL}

Desde las puertas que componen los enmarcamientos ornamentales que rodean las más suntuosas miniaturas principales accedemos a las zonas donde lo marginal y la drôlerie son los únicos competidores de lo escrito. En estas páginas se acentúa la dimensión fantástica del ornamento y quizás también su carácter de universo alternativo ${ }^{14}$. Entramos de alguna manera en el "bosque de la marginalia", concebido como un mundo fantástico donde todo puede suceder y todo puede ser visto.

Los personajes antropomorfos aparecen adaptados al medio ornamental en que desarrollan sus ejercicios como virtuosos equilibristas del espacio, en los márgenes de una escritura de trazo seguro y visualmente sugerente, sobre todo para los que no somos capaces de descifrarla y la vemos como decoración abstracta que se convierte en forma que acompaña las figuraciones de un tejido gráfico peculiar pero más familiar e identificable (figs. 9-13).

Entre los temas que componen este nuevo universo puede aparecer la cabeza humana. Se emplaza sobre la página independiente del cuerpo antropomorfo. Por ejemplo, hay que destacar una magnífica testa barbada que se sitúa en el folio 24 (fig. 10). La cabeza del insondable personaje aparece cubierta con una tela roja, a manera de capuchón abierto, que cuelga de ambos lados. El personaje en cuestión, un “hombre" de edad avanzada, nace de una rama pseudo-vegetal que le confiere una vida similar a la del fruto ${ }^{15}$. La testa parece depender de la sabia vehiculada

14 Sobre el sentido de la marginalia vid., SCHAPIRO, Meyer, “lmágenes en los márgenes y drôlerie", en Estudios sobre el arte de la Antigüedad tardía, el Cristianismo primitivo y la Edad Media. Madrid 1987, págs. 179-181. También Pasqua, Camilla, "Lo sviluppo delle "drôleires" nella miniatura medievalem. Arte in Friuli, Arte a Trieste. Udine 1989, págs. 45-56.

15 ALCOY, R., "Rostres profans i marginalia...", notas 21 y 31 , donde destacamos la representación de la cabeza unida a una orla vegetal como fruto más o menos máduro, según la edad del personaje que sintetiza. 


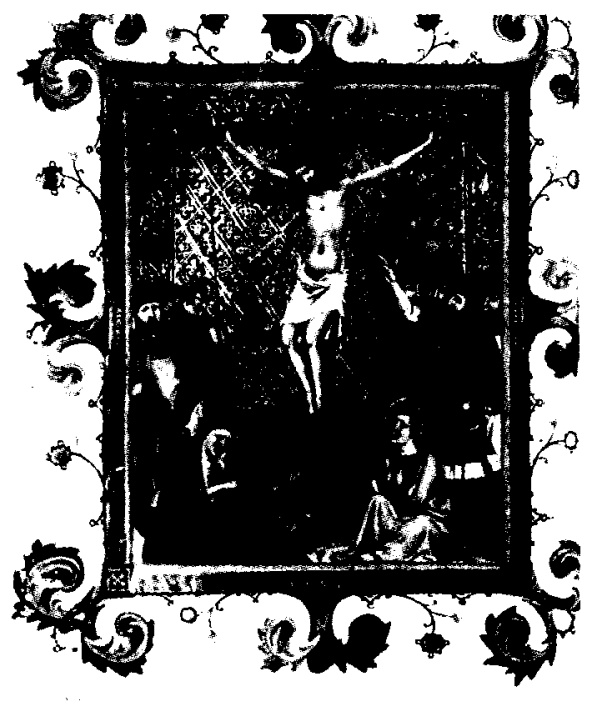

Fig. 3. Libro de Horas de María de Navarra, fol. $241 \mathrm{v}$.

Fig. 5. Libro de Horas de Maria de Navarra, fol. 154.

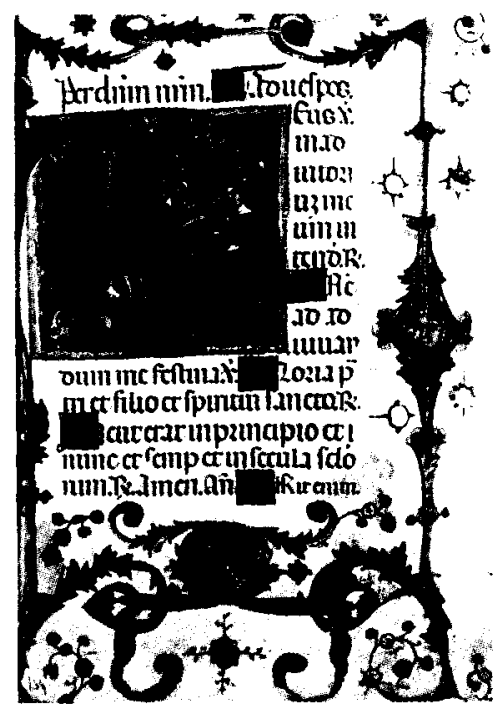


Fig. 6. Marginalia del Libro de Horas de María de Navarra, fol. 7.
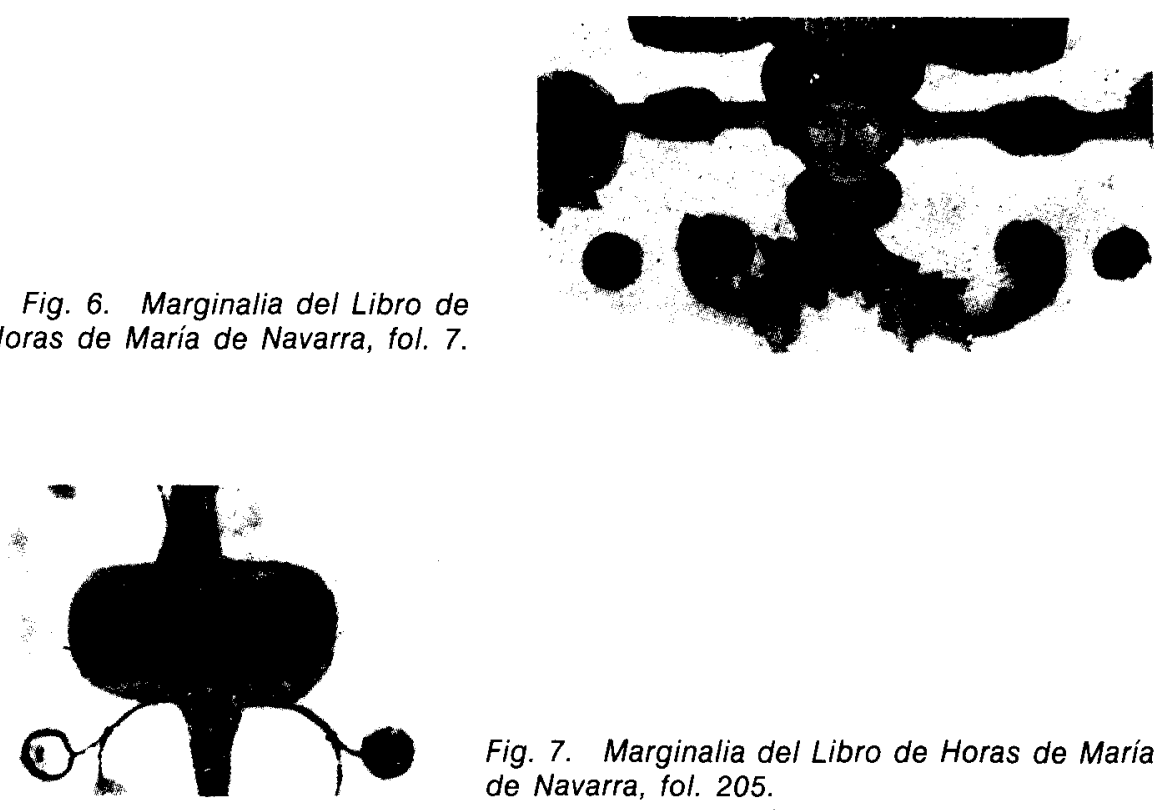

Fig. 7. Marginalia del Libro de Horas de María de Navarra, fol. 205.

Fig. 8. Marginalia del Libro de Horas de María de Navarra, fol. 342.

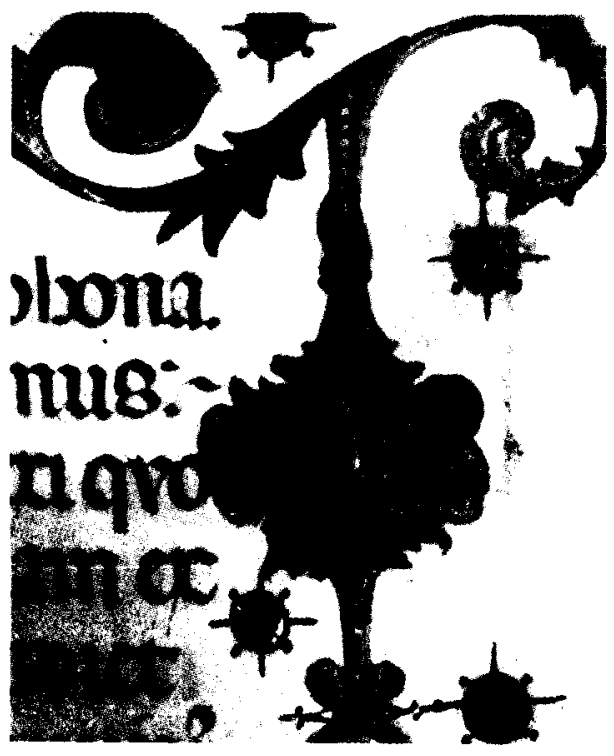


フルை

Iחק

2537

an2)

xख?

ive

exy

7205

Nopr

270

$\gamma$ cis

iोis|

27

200

bisis

bits

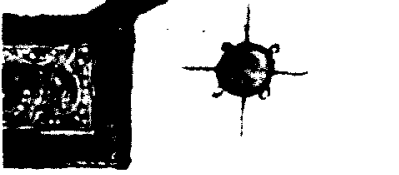

$\cdots$

Fig. 10. Marginalia del Maimónides de Copenhague, fol. 24.

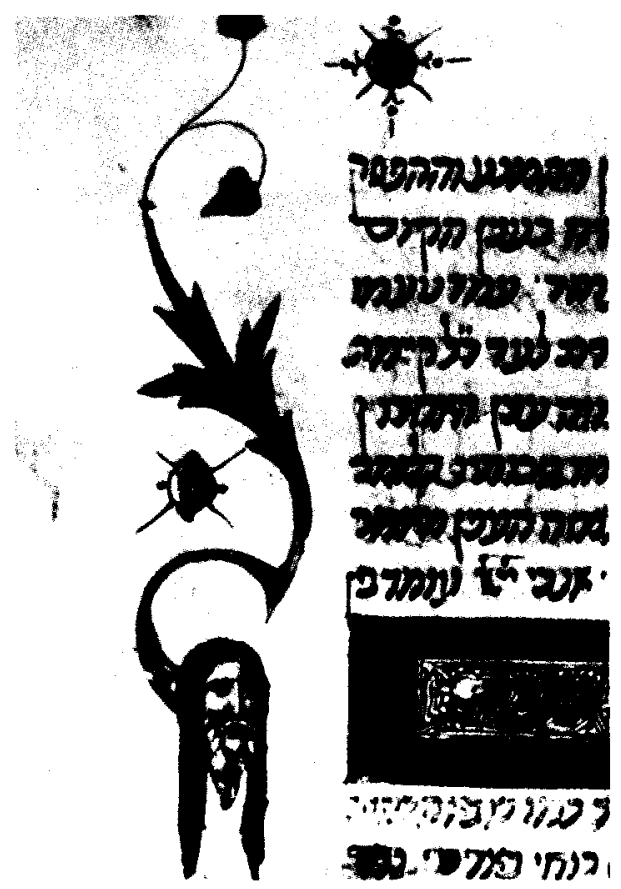




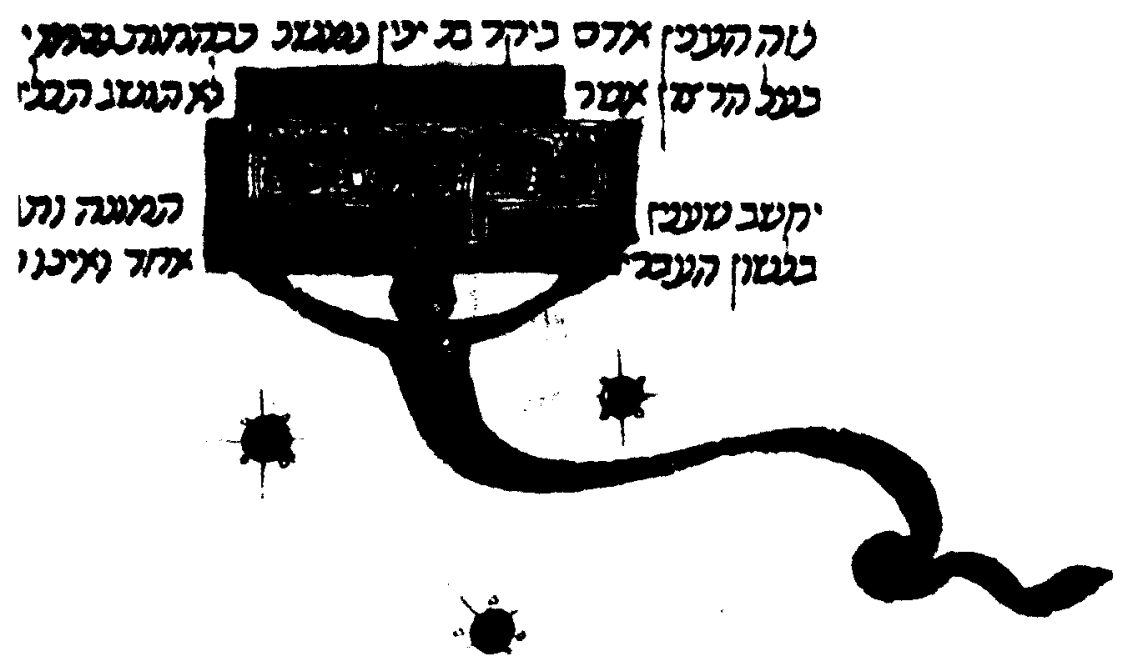

Fig. 11. Marginalia del Maimónides de Copenhague, fol. $18 \mathrm{v}$.

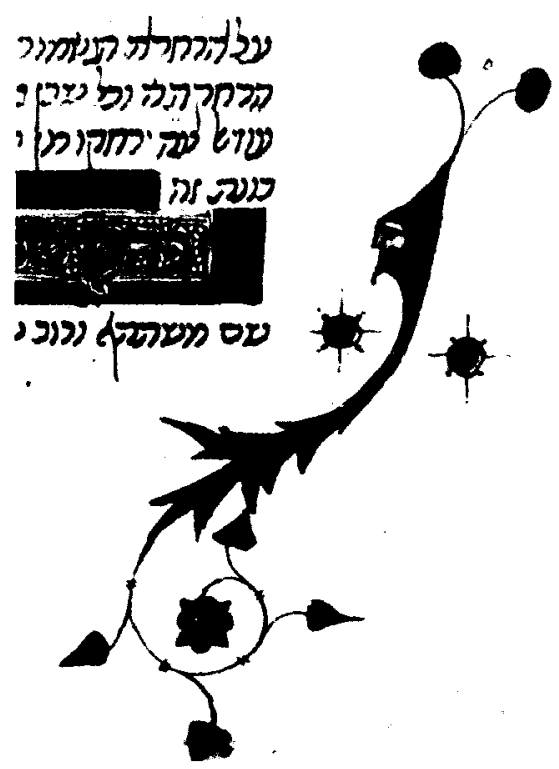

Fig. 12. Marginalia del Maimónides de Copenhague, fol. $41 \mathrm{v}$.
Fig. 13. Marginalia del Maimónides de Copenhague, fol. $153 v$.

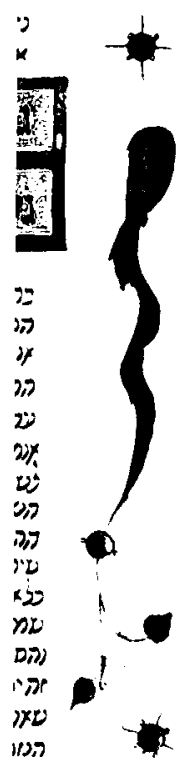


por el tronco vegetal. Seguramente no podemos cortar la rama sin desfigurar la fantasía que se refiere a un árbol de la vida; sin embargo el sentido cambia cuando nos damos cuenta de que es posible dar la vuelta a esta idea y pensar en la cabeza como lugar de nacimiento de un tronco que genera una gran hoja de acanto rematada por dos pequeñas hojas acorazonadas. La ejecución particularmente cuidada de esta cabeza, que puede recordar la representación del judío encapuchado, su volumen especialmente definido y convincente, contrasta con su implantación irreal, casi surreal, en el plano figurado. Otras imágenes semejantes, nunca iguales, aparecen en los folios 41v. (fig. 12), 92v., 95, 98v., 99, 153v. (fig. 13), 187 ó 215. En algunas se llega a insinuar el cuerpo de los encapuchados, pero se trata de un cuerpo vegetal compuesto por las hojas del acanto $y$ otras floraciones que favorecen cualquier movimiento en el espacio. En el folio 135, abajo a la derecha, un rostro humano de perfil se inscribe entre el acanto y la forma romboidal que prolonga sus cabellos estirados hacia arriba. Es un primer paso a la desaparición parcial de la cabeza. Pronto quedará visible solamente la cara que puede adoptar incluso la forma lobulada o romboidal. Así sucede al menos en una serie de figuraciones que ya habian tenido campo de experimentación en el Libro de Horas de María de Navarra y que se utilizan de nuevo en este libro (folios $35 \mathrm{v} ., 142 \mathrm{v} ., 198,252,297)$ camufladas entre los entrelazos vegetales o subrayadas por estos.

Observamos una composición distinta en el busto recortado sobre la hoja vegetal anudada del folio $64 \mathrm{v}$. O en aquel otro que mira con insistencia un título en el folio $92 \mathrm{v}$. Más completas aún resultan las figuras antropomorfas que, a manera de ángeles sin alas, sostienen por debajo las cartelas de algunos títulos, en el folio 18v. (fig. 11) y en el 115. Tanto una como otra, diferenciadas por la edad, se encuentran en vuelo. Las piernas, elemento del que carecen la mayor parte de los seres humanizados que viven en los márgenes del Maimónides, son sustituidas ahora por nuevos elementos vegetales o por una prolongación del ropaje que no deja entrever ni sospechar su presencia. La solución concreta permitiría emparentar a estos sujetos con los ángeles que portan un escudo en la zona inferior del folio $37 \mathrm{del}$ Llibre Verd o con el portador de una cruz procesional que aún careciendo también de alas ostenta, en el folio 136 del mismo libro, un manto prolongado y volador que se anuda antes de dibujar un dinámico remate. Otro habitante familiar de los que acabamos de citar se sitúa en el pie de página del folio $176 \mathrm{v}$., debajo de un nuevo título. Sin embargo, su actitud es distinta, ya que este personaje, al margen de la leyenda, parece enfrascado en describir una figura simétrica que obliga a emplazar su cola vegetal en el lado opuesto al que ocupará 


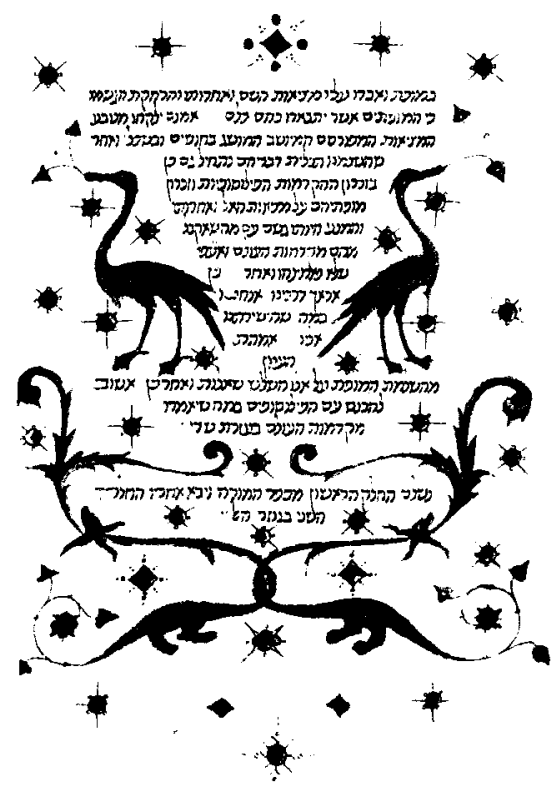

Fig. 14. Marginalia del Maimónides de Copenhague, fol. $112 \mathrm{v}$.

el fragmento de orla que el mismo, actuando como eje de la composición, sostiene.

Finalmente, hay que destacar también la presencia de una única figura masculina descrita de cuerpo entero. Esta efigie, completamente desnuda, nos sorprende en el margen derecho del folio 188v. (fig. 9). El joven personaje, con los brazos cruzados sobre el pecho, se apoya acrobáticamente sobre la repisa de un título con el pie izquierdo, mientras juega con el contrario a tocarse la cabeza.

\section{DRAGONES Y OTRAS ESPECIES}

Hay que detenerse en el folio 112v. (fig. 14). Una composición simétrica juega plásticamente con los espacios dejados por el texto, que se agranda y se estrecha diversas veces para dejar lugar a derecha e izquierda a dos aves acuáticas, una azul y otra naranja, de largas patas palmeadas, y a una pareja de dragones, uno verde y el otro amarillo, que con unos larguísimos cuellos entrelazados y una estilización casi "lineal", sobre el punteado de botones de oro, abren sus respectivas fauces de las cuales han de salir hojas de conformación grasa que son la base de la marginalia 
del libro. Estos fantásticos animales tienen numerosos congéneres en el Maimónides de Copenhague. Camuflados en la decoración de los folios, quizás no tan claramente destacados como los que se han citado ahora, se convierten en una notación zoomórfica sorprendente por su disposición y por las contorsiones afiligranadas de su anatomía. Los cuellos y colas de estas bestias resultan excepcionales si los comparamos a los que encarnan a sus iguales en el Libro de Horas de la reina María ${ }^{16}$.

En el Maimónides, el dragón, a veces configurado como variante de animales más domésticos, puede querer morder la cartela de un título, y puede llegar a morderla realmente (folios 17, 19, 32 [fig. 15], 266), puede tocarla o emerger de ella (40v., 94, 257v., 249, 257v.), puede encararse a ella (folios 63v. [fig. 16], 91v., 115v., 136), y también es posible que le de la espalda (folios $43,86 \mathrm{v}$.) o que acabe por superponerse a la misma (folio 216). Es factible asímismo que el dragón y sus parientes se situen indiferentes ante el título; sin embargo, su presencia queda asociada a la de estos. Sus formas y actitudes demuestran la habilidad del miniaturista para multiplicar sus recursos a lo largo del libro, concretamente hasta el folio 318 , donde se interrumpe la decoración figurada que asociamos al taller de Ferrer Bassa y se produce un notable cambio también en la configuración de las leyendas principales del texto, aquellas que hasta este momento eran subrayadas por enmarcamientos dobles rectangulares y, todavía más, por las notas y acentos de una compleja marginalia.

Los dragones de este códice, más estilizados que nunca, saben caminar boca abajo con un botón de oro en la boca (folio 43,293 ) o sin él (folio 216v., 257v.). Son capaces de casi desaparecer entre el follaje (folio 116) y de convertirse en serpiente que atraviesa un encabezamiento (folio $274 \mathrm{v}$.). Pueden adaptarse a la vida vegetal que se les propone del mismo modo que hemos visto como lo hacia el hombre. También aquí los cuerpos de acanto y las colas florales que generan toman carta de naturaleza (folios 63, 86v., 91v., 136, 194v. [fig. 20], 216...); menos normalizado es el vómito de elementos vegetales -es decir, el animal con flores o tallos saliendo de su boca- pero no por ello resulta un ejercicio imposible (folio 93).

Los dragones del folio 112 y sus congéneres podrán compararse con el amplio repertorio de animales fantásticos del Libro de Horas de María de Navarra. Sin embargo, en el códice de la reina no hemos podido hallar figuras tan desmaterializadas como estas, que, sin perder ápice de la

16 Véanse los dragones del folio 144 en el margen inferior de una página iniciada por una majúscula "D" que incluye la figura de San Juan Bautista. 


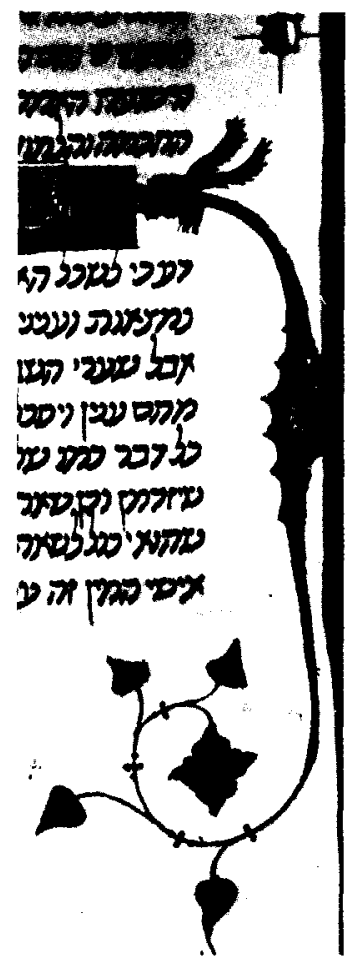

Fig. 15. Marginalia del Maimónides de Copenhague, fol. 32.

Fig. 16. Marginalia del Maimónides de Copenhague, fol. 63.

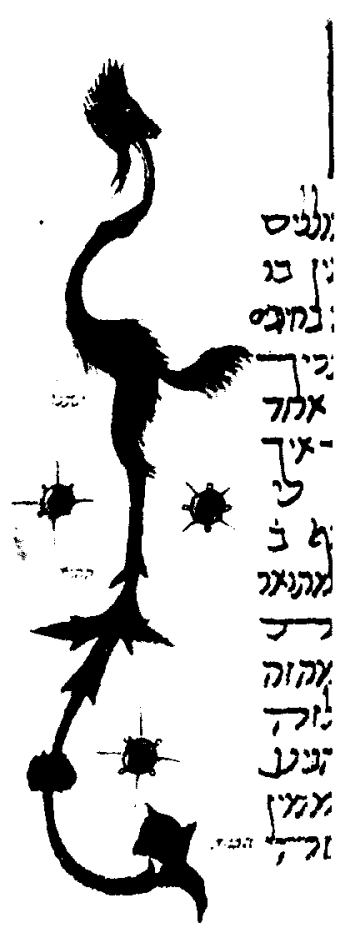


Fig. 17. Marginalia del Maimónides de Copenhague, fol. $168 \mathrm{v}$.

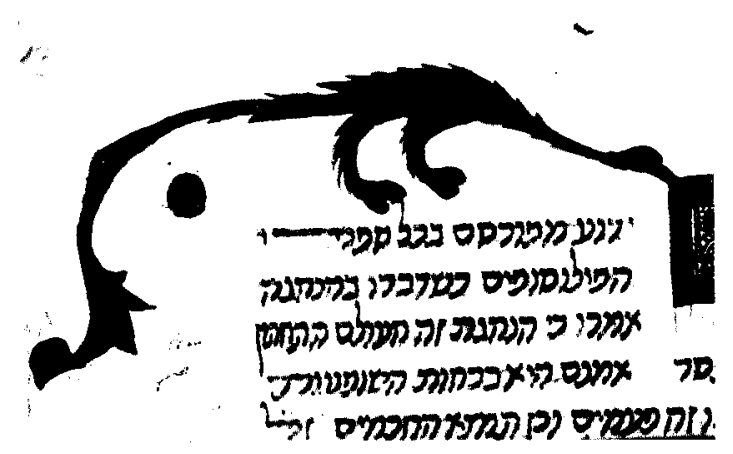

Fig. 18. Marginalia del Maimónides de Copenhague, fol. 130. 
intensidad gráfica de sus volúmenes, los condensan y modelan hasta convertirlos en puro grafismo. Sin embargo, nos enfrentamos a un grafismo anecdótico que nos permite descubrir sus apariencias cuando fijamos la mirada en el elemento vegetal que, inusitadamente, se convierte en ser fabuloso o en personaje imposible y metafórico.

Retornando al tema de las aves, las que se representan en el folio 112v. del Maimónides (fig. 14) pueden emparentar con las que una mujer, arrodillada sobre una orla, aferra por el pico en el folio $140 \mathrm{v}$., del oracional de Venecia ${ }^{17}$. Las aves acuáticas dominan en el catálogo del libro. Una de ellas, con el pico entreabierto, posa sobre un curioso letrero del que emerge una pierna (folio 31). Otra ave zancuda se sitúa sobre un botón floral y toca con la punta de su largo pico uno de los letreros del texto estableciendo con él una relación paralela a la que hemos atribuido a algunos dragones (folio 44) (fig. 21). Por otro lado, también las aves pueden metamorfosear las plumas por cuerpos y excrecencias vegetales (folios 50, 98,109,144, 153), por colas y alas de acanto. En algún caso puntual asistimos a mutaciones que permiten que el pájaro adopte el cuerpo del dragón (folios 103, 130) o viceversa, que el dragón se convierta parcialmente en ave zancuda (folios 63, 93).

Algunas de estas especies monstruosas son difíciles de identificar dado el alto grado de estilización (íolio 168v. [fig. 17], 311). En otros casos, el juego con la drôlerie lleva al miniaturista a convertir el cuerpo del animal en una especie de rueda sobre la cual gira su cabeza; ésta aparece anudada a un extremo por el cuello mientras muerde el lado contrario, con lo que se acaba de conformar su estructura circular. A todo ello, al círculo completo, se añade la ironía de una cola vegetal (folio 179v).

Estas bellas bestias, fantásticas en su mayoría, difícilmente nos sugieren un significado simbólico de carácter negativo. No parecen definir aquí un mundo demoníaco si en algún momento, anterior o posterior, pudieron describirlo. Los rostros de algunos de estos seres emparentan con los del reino animal más próximo; el perro o el caballo, incluso el gato, parecen sugerir ideas al pintor. En cualquier caso éste nos deja salir de lo grotesco más cruento para dirigirse a una encrucijada gráfica que se interesa por la drôlerie en su vertiente amable, que si resulta esforzada lo es sólo por

17 Hay que notar que este mismo códice incluye un elenco de aves digno de aprecio, con las que podrían compararse la mayoría de las representadas en el Maimónides, al menos las situadas en torno a las miniaturas principales. No sucede lo mismo cuando buscamos paralelo a los extraños especímenes gráficos en que el autor del Maimónides convierte a otros seres, repartidos y camuflados a lo largo del libro, si bien debe admitirse que el repertorio de dragones del oracional de la reina es también sumamente atractivo y rico en variantes. 


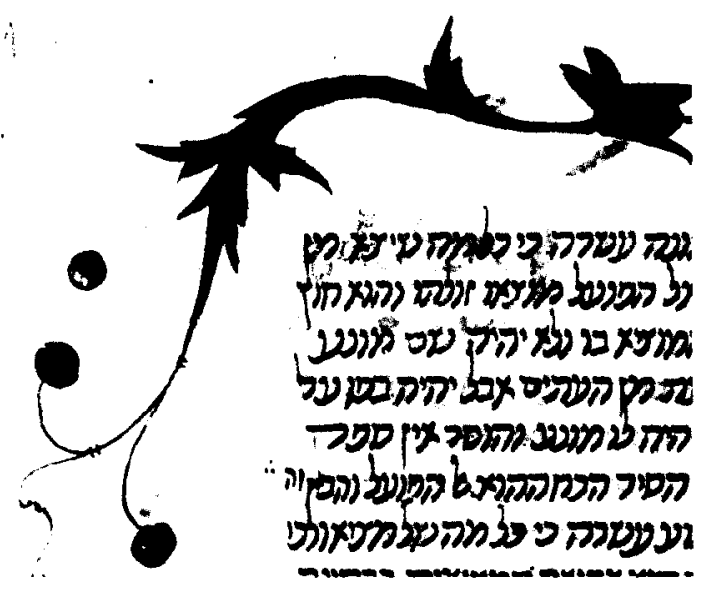

Fig. 19. Marginalia del Maimónides de Copenhague, fol. 116.

Fig. 20. Marginalia del Maimónides de

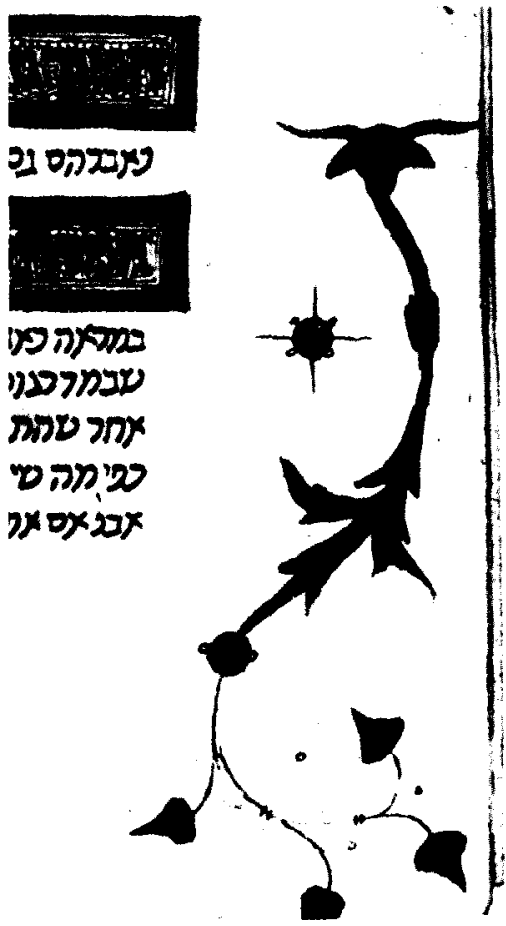

Copenhague, fol. 194v. 


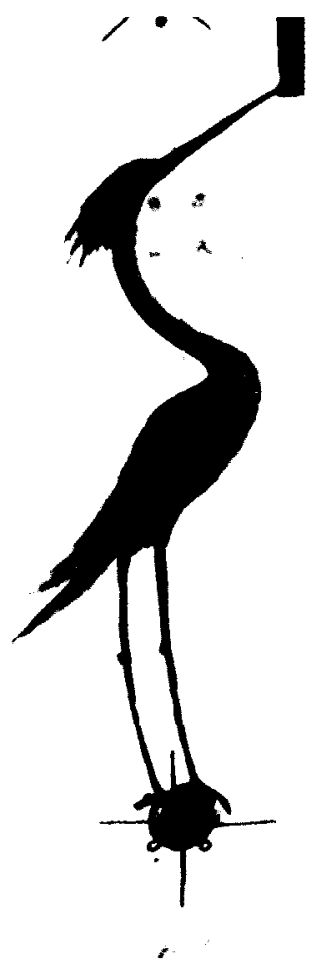

Fig. 21. Marginalia del Maimónides de Copenhague, fol. 44.

su agudeza plástica. No se trata de herir con una comicidad a ultranza la sensibilidad del lector, sino de definir gracias a una amplia galería de seres hibridos y singulares el atractivo del códice. El desplazamiento hacia lo sorprendente puede provocar nuestra sonrisa, sobre todo porque podemos acercarnos sin miedo a estas imágenes convertidas en divertimento formal y poético, y asímismo significativo.

No es nuestra intención buscar ahora los orígenes de los temas marginales representados en el Maimónides. Para todos es posible hallar interesantes precedentes. Sin embargo, el propósito ha sido, más que referirnos a ellos, destacar la originalidad de estas miniaturas dentro del contexto inmediato al que pertenecen. En síntesis, es posible aludir a su carácter peculiar constatando la sorprendente versatilidad, flexibilidad y dinamismo de los seres fantásticos representados en el códice. Hemos observado como éstos, también protagonistas en el libro, tienden progresivamente a la desmaterialización de sus cuerpos, dado ventaja, por otro lado, a una implantación cada vez mayor de elementos pertenecientes al 
reino vegetal en sus propias figuras. Sabemos ya que la efigie humana no escapa a estos experimentos gráficos.

\section{A MANERA DE CONCLUSIONES. DE FERRER BASSA A MENAHEM BESALEL}

Seguramente habría que añadir un interrogante a estas conclusiones, simbolizando la necesidad de retornar en un futuro sobre los temas que hemos entreabierto desde una perspectiva que hemos querido calificar de "formal" a sabiendas de que el paso al contenido visual del libro se describe también en este ámbito. En la comunicación sintetizamos un trabajo que debe prolongarse todavía más en función del «significado" que cabe atribuir a los elementos congregados en la decoración del manuscrito, y que exigirán, sin duda, nuevas precisiones. En función de lo expuesto habrá que interpretar este último apartado.

En nuestra opinión es posible situar la Guía de Perplejos de Copenhague entre las últimas aportaciones del taller de Ferrer Bassa. Sería, por tanto, el libro que representaría una cronología más avanzada entre las producciones que hasta ahora conocemos. Desde el momento en que se realizara la ilustración del Salterio de París hasta este último período que puntúan obras como el Libro de Horas o las pinturas de Pedralbes, deberíamos enfocar una evolución que introduce nuevos colaboradores en un taller cada vez más destacado. Sobre la línea del estilo ya formado se observan oscilaciones que nos aproximan y nos alejan de lo italiano y del estilo de un maestro, o maestros, principales ${ }^{18}$. Asistimos a la introducción de nuevos elementos que nacen de la dialéctica del taller con los obradores catalanes contemporáneos que utilizarán lenguajes artísticos semejantes, especialmente cuando abordamos el campo de la miniatura. Aunque la ambición y complejidad de unas y otras empresas no son siempre comparables, si en el Salterio de París Ferrer Bassa trabaja la mayor parte del tiempo en solitario, es posible que también lo haga en

18 Del 1340 en adelante las nuevas aportaciones al taller de Ferrer Bassa, encabezadas por Arnau Bassa y el artista conocido como "Maestro del tríptico de Baltimore", abren camino hacia nuevos componentes italianos que son indicativos, en más de un caso, del peso específico que irá cobrando Aviñón. La ciudad de los Papas, convertida en lugar de intercambios artísticos franco-italianos, también permite la articulación de enlaces provenzales entre lo catalán y lo italiano, que tendrán especial repercusión en la segunda mitad del siglo. Esta perspectiva que se despeja ahora para lo catalán será importante, por tanto, únicamente después de una etapa previa de introducción del lenguaje italianizante postgiottesco. En este momento anterior al despliegue de las componentes aviñonesas, entre las cuales puja la tendencia filosienesa, hay que fundamentar consecuentemente la importancia de la aportación de Ferrer Bassa. 
el Maimónides si nos referimos a la "gran miniatura", por contraste con lo que sucede en las Horas de María de Navarra donde es un equipo complejo el que trabaja. Una cuestión distinta, y más difícil de resolver, nos enfrenta a los "universos marginales" peculiares del Maimónides.

Para explicar la marginalia del códice habrá que estudiar —una vez comparada esta obra con otros códices relacionados con el taller bassiano- los modelos judíos que potencialmente puedan haberse tomado como punto de referencia en el momento de ilustrar el texto de la Guía de Perplejos. En función de los mimos quizás pueda observarse algún tipo de repercusión en la factura general, y más específicamente en la dimensión «iconográfica" de estas miniaturas. El dragón y también sus metamorfosis vegetales son imágenes comunes en algunos códices hebreos. Cabe advertir como hemos intentado hacerlo que, si bien estos motivos tampoco no son ajenos a la tradición cristiana, si existe un cierto particularismo formal respecto a las obras catalanas que se encuentran más próximas al Maimónides. En este sentido, puede pensarse en la utilización de un modelo "judío" que sirviera de pauta a Ferrer Bassa. Sin embargo, es difícil y hasta cierto punto inútil intentar disociar el manuscrito que pudo servir de orientación de los estilos vigentes en la primera mitad del siglo xIv, para hablar de una miniatura ujudía" que el pintor de $\mathrm{Pe}$ dralbes utilizara como pauta. Es posible que el manuscrito que sirviera de modelo fuera en realidad la obra de un miniaturista cristiano, y cabe mayor certeza aún sobre la vinculación entre los lenguajes plásticos que encontraremos, variando sólo según la época, tanto en los códices judíos y como en los cristianos. El hecho es que la suma estilización de que gozan las imágenes marginales de este libro nos sugiere la presencia de una obra de carácter «lineal» que quizás sirviera de inspiración al maestro italianizado a que lo atribuimos ${ }^{19}$. En este sentido, los modelos a que hacemos referencia tal vez se situarian dentro del episodio estilístico del gótico lineal y serían obras más antiguas, datables probablemente entre el último cuarto del siglo XIII y el primer tercio del XIV. Aunque dejemos momentáneamente en suspenso su demostración, esta hipótesis sería particularmente sugestiva. Si Ferrer Bassa, en una obra que corresponde al último momento de su actividad, supo apreciar y elegir algunas de las

19 Recordemos, sin que nuestra pretensión sea establecer una relación inmediata, el manuscrito del Misné Torá (Segunda Ley) copiado en Colonia en 1294-1296 (vid., Maimónides y su época... n. 59, págs. 149-150, doncie se añaden otras referencias bibliográficas). Se trata de un códice ilustrado en estilo lineal o "francogótico" que incluye temas -el dragón de cola vegetal, los pequeños monstruos de cuellos alargados que se entrelazan desarrollados con posterioridad por el artífice que trabajaría en la Guía de Perplejos de Copenhague. 
resultantes plásticas del estilo «lineal», en esta premisa nos descubre su receptividad artística y, al mismo tiempo, nos habla de su capacidad para explotar un texto gráfico de características muy diversas a las propias sacándole partido a su favor. Sobre esta base destacamos su reinterpretación solamente en los temas de los márgenes, que fueron los más libremente esbozados del manuscrito - ya conocidos en una versión menos desmaterializada en las Horas de Maria de Navarra- definiendo una perspectiva original que, con o sin fuentes de inspiración iconográfica, resulta uno de los grandes atractivos de este libro. Es obvio que en contrapartida también deberá tenerse en cuenta una plausible repercusión de estas miniaturas en la ilustración de otros códices judíos. El llamado Hagadá de Barcelona de la Brithish Library (Add. ms. 14761) nos aproxima al contexto de mediados del siglo xIV a través de una obra rica en decoración marginal, inferior en calidad pero no muy alejada en cuanto al concepto pictórico general del italianismo que con mayor maestría quedó reflejado en el Maimónides.

En las miniaturas principales notamos la dependencia respecto a una factura pictórica de pinceladas visibles que caracteriza al maestro del $\mathrm{Sal}$ terio parisino y que nuevamente queda referida al Maimónides, a la vez que redescubrimos la riqueza cromática y, en definitiva, el carácter de sus tipos, dotados de una personalidad y fuerza sobresalientes, que los hace casi inconfundibles. En el Hagadá de Barcelona se divisa tan sólo un leve reflejo de esta concepcion pictórica, pero algunas de sus fórmulas quedan implicadas tanto en los márgenes como en la ilustración principal ${ }^{20}$.

Por otro lado, hay que advertir el acierto en la aproximación de la factura del códice de Copenhague a un manuscrito hebreo de la Bilioteca Nacional de París - ms. hebr. 1203-, una recopilación de tratados de medicina, ya que ambos nos sitúan en una coordenada artística semejante, en tanto pueda centrarse su realización en el marco catalán trescentista ${ }^{21}$. Sin embargo, deben hacerse algunas puntualizaciones sobre la factura de ambos libros, que en el artículo de G. Sed-Rajna se consideran dependientes del "taller del Maestro de San Marcos". En primer lugar, hoy por hoy es difícil seguir hablando de este taller sin establecer distinciones que hemos tenido en consideración al comenzar, y que implican una diferenciación clara de las obras de Ferrer y Arnau Bassa. En segundo lugar, si bien es posible admitir el parentesco genérico que se

20 Vid., Goldstein, David, “La Hagadá de Barcelona», FMR, vol. I. n. 3, 1990, págs. 39-67, con excelentes reproducciones del manuscrito. Véase también el facsímil publicado en Londres, 1992 (ed. J. Schonfield).

21 Sed-RajnA, G., “Ateliers de manuscrits...”, pág. 342. 
detecta en el estilo de los dos manuscritos hebreos de París y Copenhague, resulta mucho más peligroso referirlos a la misma mano. De hecho, en el códice ms. hebr. 1203 reaparecen algunas de las fórmulas ornamentales que hemos visto en el Maimónides, pero su trazado es menos enérgico y ritmado, la disposición de los elementos más sumaria y pobre en inflexiones. Algo parecido sucede si tenemos en cuenta las ilustraciones principales. En su conjunto quizás se centre la actuación de un artista menor, posiblemente cercano al taller barcelonés y conocedor de sus esquemas, pero inferior en resultados si la comparación se establece con Ferrer Bassa.

Al plantear la relación entre un comitente judío y el taller de los Bassa deberán tenerse en cuenta los datos conocidos sobre la proximidad de Ferrer a algunos de los habitantes del call de Barcelona - muy cercano al lugar donde el pintor tenía abierto su taller- pero asímismo habrá que considerar la vinculación del pintor a la corona catalana, que despeja indudablemente un notorio enlace con las aljamas, consideradas de su propiedad. Por otro lado, la reconstrucción biográfica que David Romano hace de Menahem Besalel, médico a quien se destinaba esta copia de la Guía de Perplejos, permite insistir en esta serie de correspondencias en que el rey puede actuar como mediador o favorecer un mutuo conocimiento entre el físico judío y aquel que fue el más apreciado pintor de Pedro el Ceremonioso, ya que parece ser que también el comitente del libro, como Ferrer Bassa, se hallaría al servicio del mencionado monarca ${ }^{22}$. El Menahem que estuvo al servicio del rey pudo morir antes del 3 de marzo de $1349^{23}$. Ferrer Bassa desaparece en una fecha imprecisa del 1348. Por tanto, el periodo en que pudo ilustrarse el manuscrito nos devuelve necesariamente al año que simboliza la Peste Negra.

Otras noticias involucran, asímismo, a las aljamas, supeditadas a la voluntad del rey, en la dinámica del taller de los Bassa. La documentación enuncia, por ejemplo, los pagos que los judíos barceloneses debieron efectuar a Ferrer por el importe de una serie de trabajos que este había realizado para el Palacio real de Barcelona, según documento fechado a

\footnotetext{
22 Con anterioridad al 1345 el maestro Menahem habría estado al servicio o en relación con la corte de Jaime III de Mallorca, valorándose su capacidad de umagnus experimentator et nigromanticus». Parece factible que en el curso del 1345 se convirtiera ya en físico real en la corte del Ceremonioso: «magistrum Menahem, fisicum domus nostre»; para todo ello, y también para los problemas que presenta la fijación de su personalidad, véase el texto de ROMaNO. D., “En torno a Menahem...", pág. 98.

23 El 12 de marzo de 1349 el rey ordena la devolución de 500 sueldos a los hijos y herederos de Menahem (vid. Romano, D. “Entorno a Menahem...", pág. 98.
} 
10 de junio de $1348^{24}$. Otros datos en la misma dirección los aporta la escritura de Vidala, viuda del judío Isaac García, que recibe en abril de 1349 del fiador de los Bassa diversas cantidades que estos le debían ${ }^{25}$. Una tercera vía, tal vez más indirecta, permite recordar la relación de Ferrer Bassa con un pintor llamado Barata, que aparece como testigo en 1346 y que nos conduce hasta un escrito en que un tal Francesc Barata, hijo de Ramón Barata (o Ramón Davidi), ante dos pintores más, Bartomeu Barata, su hermano, y Arnau Samet, entra al servicio de un escultor (y pintor) destacado, Aloi de Montbrai. En su día nos preguntamos si estos artistas, desconocidos por el momento, podrían tener alguna relación con la comunidad hebrea y con otros pintores que podrían ser considerados también miniaturistas, Bernat Vitalis y Bernat Villibus ${ }^{26}$.

En definitiva, La Guía de Perplejos, miniada por un taller barcelonés en una fecha necesariamente cercana a los años en que hemos visto cabe cifrar esta copia - datable entre el 6-9-1347 y el 24-8-1348, nos sugiere, a pesar de los matices introducidos en la concepción de los marginalia, el área de influencia más inmediata a Ferrer Bassa. Descartado su hijo Arnau -el «Maestro de San Marcos"- en función del estilo, pensamos que pueda tratarse de una obra ilustrada en 1348 directamente por el Maestro de la capilla de San Miguel de Pedralbes, aunque no deba descartarse por completo la colaboración de algún artista secundario.

24 López Meneses, Amada, "Documentos culturales de Pedro el Ceremonioso", Estudios de Edad Media de la Corona de Aragón, vol. V. Zaragoza 1952, pág. 677, doc. 10.

25 Madurell I MARImON. Josep $\mathrm{M}^{\mathrm{a}}$, El pintor Lluís Borrassà. Su vida su tiempo, sus seguidores y sus obras, 3 vols. Barcelona 1949-1952, III. Addenda al apéndice documental, (Anales y Boletín de los Museos de Arte de Barcelona, vol. X), 1952, doc. 393, págs. 22-23.

26 Vid. MadureLL, J. M. El pintor... VII, 1949, págs. 214 y 215 y págs. 214-215; ALcoy, R., La introducció $i$ derivacions..., vol. I, págs. 58-59. 